\title{
Self Esteem Dan Group Cohesiveness Sebagai Pemoderasi Pengaruh Partisipasi Anggaran Pada Budgetary Slack
}

\author{
Anak Agung Ngurah Bagus Dwiprayuda ${ }^{1}$ \\ I Dewa Nyoman Wiratmaja ${ }^{2}$
}

\author{
${ }^{1,2}$ Fakultas Ekonomi dan Bisnis Universitas Udayana (Unud), Bali, Indonesia \\ e-mail: gunkyuda@yahoo.co.id
}

\begin{abstract}
ABSTRAK
Perilaku manajemen dalam proses penyusunan anggaran suatu perusahaan dapat menimbulkan kecenderungan manajer dalam mencipatakan bugetary slack. Tujuan penelitian ini untuk mendapatkan bukti empiris kemampuan self esteem dan group cohesiveness sebagai pemoderasi pengaruh partisipasi penganggaran pada budgetary slack. Penelitian ini dilakukan pada 22 BPR se-Kota Denpasar. Teknik penentuan sampel dalam penelitian ini adalah teknik purposive sampling, dengan jumlah responden sebanyak 84. Teknik analisis yang digunakan dalam penelitian ini adalah Moderated regression analysis (MRA). Hasil dari penelitian ini menunjukkan bahwa baik self esteem maupun group cohesiveness mampu memoderasi pengaruh partisipasi anggaran pada budgetary slack di BPR se-kota Denpasar. Semakin tinggi self esteem dan group cohesiveness akan memperlemah pengaruh partisipasi anggaran pada budgetary slack.

Kata kunci: partisipasi anggaran, self esteem, group cohesiveness, budgetary slack
\end{abstract}

\begin{abstract}
Behavior management in the process of preparing a company's budget can lead to the tendency of managers in creating bugetary slack. The purpose of this study to obtain empirical evidence of the ability of self esteem and group cohesiveness as a moderator of the influence of budgetary participation on budgetary slack. This research was conducted at 22 BPR in Denpasar City. The technique of determining the sample in this research is purposive sampling technique, with the number of respondents as much as 84 . The analysis technique used in this research is Moderated regression analysis (MRA). The results of this study indicate that both self esteem and group cohesiveness are able to moderate the influence of budgetary participation in budgetary slack at BPR in Denpasar city. The higher self esteem and group cohesiveness will weaken the effect of budgetary participation on budgetary slack.
\end{abstract}

Keywords: budget participation, self esteem, group cohesiveness, budgetary slack

\section{PENDAHULUAN}

Perbankan memiliki peran yang sangat penting dalam peningkatan pembangunan ekonomi suatu negara memalui jasa keuangan dalam menopang dan membantu meningkatkan perekonomian masyarakatnya, hampir setiap transaksi ekonomi dalam masyarakat berhubungan dengan bank. Pertumbuhan perekonomian yang terus berkembang menuntut eksistensi bank untuk melayani masyarakat dan 
ketatnya persaingan bank yang mulai melirik pasar mikro. Salah satu jenis bank yang dihadapkan pada persaingan yang ketat adalah Bank Perkreditan Rakyat (BPR), sehingga menuntut BPR melakukan pengendalian manajemen sebagai sarana untuk menetapkan perencanaan, koordinasi, dan evaluasi jalannya kegiatan perusahaan agar lebih baik.

Menurut Peraturan Otoritas Jasa Keuangan Nomor 37/POJK.03/2016, dalam rangka mencapai tujuan usaha sesuai dengan visi dan misi yang telah ditetapkan, Bank Perkreditan Rakyat perlu menyusun rencana bisnis secara realistis setiap tahun dengan memerhatikan faktor ekstern dan intern yang dapat memengaruhi kelangsungan usaha Bank Perkreditan Rakyat, prinsip kehati-hatian, dan asas perbankan yang sehat. Rencana bisnis harus disusun secara matang, realistis dan komprehensif, sehingga dapat digunakan sebagai dasar untuk memberikan arah kebijakan dalam melaksanakan kegiatan usaha untuk mencapai visi dan misi Bank Perkreditan Rakyat. Untuk melakukan tugas-tugas tersebut diperlukan kemampuan manajemen dalam mengelola dan mengalokasikan sumber-sumber ekonomis perusahaan secara efektif dan efisien (Aristianto, 2015). Salah satu alat yang dapat digunakan dalam proses perencanaan dan pengendalian rencana bisnis tersebut adalah anggaran.

Anggaran memegang peranan penting sebagai alat manajemen untuk mengendalikan operasi perusahaan agar strategi yang ditetapkan dapat digunakan untuk mencapai tujuan perusahaan. Sukarno (2002) menyatakan bahwa anggaran adalah rencana yang terorganisasi dan dinyatakan dalam unit moneter untuk operasi dan sumber daya suatu perusahaan selama periode tertentu di masa yang 
akan datang, sedangkan menurut Anthony dan Govindarajan (2007) dalam penelitian Arthaswadaya (2015) mendefinisikan anggaran sebagai suatu perencanaan dan pengendalian dalam jangka pendek secara efektif dalam organisasi. Pengertian anggaran yang lain menurut Supriyono dalam penelitian Falikhatun (2008) menyatakan bahwa anggaran memiliki dua peranan penting yaitu sebagai perencanaan dan kriteria kinerja. Anggaran sebagai perencanaan berisi tentang rencana-rencana keuangan organisasi di masa yang akan datang, sedangkan anggaran sebagai kriteria kinerja berfungsi sebagai bagian dari proses pengendalian manajemen yang dapat dinyatakan secara formal. Berdasarkan beberapa definisi anggaran diatas dapat disimpulkan bahwa anggaran merupakan cara untuk mengkomunikasikan rencana, mengelola sumber daya, menentukan tujuan dan sasaran, serta sebagai acuan penting dalam suatu organisasi.

Setiap manajemen menginginkan organisasi yang mereka kelola mencapai tujuan organisasi yang telah ditetapkan. Setiap anggota individu dalam organisasi pasti mempunyai tujuan pribadi yang tidak selalu konsisten dengan tujuan organisasi, agar sebuah organisasi mempunyai keselarasan tujuan diperlukan 
adanya manajemen pengendalian yang baik untuk menyelarasan tujuan tersebut (Arthaswadaya, 2015). Salah satu cara organisasi melaksanakan pengendalian manajemen yang berkaitan dengan penyelarasan tujuan tersebut adalah dengan menggunakan sistem pengendalian yang bersifat formal yaitu penyusunan anggaran.

Kegiatan pada proses penyusunan anggaran memiliki dampak langsung terhadap perilaku manusia, sehingga terdapat perilaku-perilaku manusia yang akan timbul sebagai akibat dari anggaran. Proses penyusunan anggaran perlu memperhatikan pihak-pihak yang terlibat dalam proses penyusunannya yaitu pihak atasan dan bawahan atau sering disebut dengan partisipasi anggaran (Winarni, 2014). Anggaran yang disusun pada perusahaan bertujuan agar manajer dapat menjalankan perusahaan secara efektif dan efisien, begitu juga dengan proses penyusunannya harus dibuat dengan teliti secara efektif dan efisien. Anggaran yang dibuat secara efektif akan mempengaruhi tercapainya tujuan perusahaan yang telah ditetapkan, sedangkan keefisienan anggaran berpengaruh terhadap tepatnya pengeluaran biaya yang dikeluarkan perusahaan agar tidak ada pemborosan dalam anggaran, sehingga suatu perusahaan harus membuat perencanaan yang matang sebelum memulai kegiatan operasionalnya untuk meminimalisasi kegagalan yang mungkin terjadi.

Proses penganggaran dapat dilakukan dengan metode top-down dan bottomup. Metode top-down merupakan metode penyusunan anggaran yang hampir seluruhnya dilakukan oleh manajemen level atas, sedangkan manajemen level menengah dan level bawah hanya melaksanakan anggarannya saja. Sebaliknya, 
metode bottom-up merupakan metode penyusunan anggaran yang dilakukan oleh manajemen level bawah kemudian dilanjutkan oleh manajemen level menengah dan disahkan oleh manajemen level atas. Sistem penganggaran pada metode bottom-up dapat meningkatkan kinerja manajer atau bawahan melalui partisipasi anggaran.

Partisipasi anggaran adalah proses yang menggambarkan individu yang terlibat dalam proses penyusunan anggaran dan mempunyai pengaruh terhadap target anggaran (Brownell, 1982). Partisipasi anggaran melibatkan semua tingkatan manajemen untuk mengembangkan rencana anggaran. Partisipasi anggaran ini diperlukan karena bawahan yang lebih mengetahui kondisi langsung bagiannya. Menurut Apriyandi (2011), semakin tinggi keterlibatan individu dalam penyusunan anggaran, maka semakin tinggi pula rasa tanggung jawab untuk melaksanakan keputusan yang dihasilkan.

Salah satu faktor yang menyebabkan terjadinya budgetary slack adalah partisipasi anggaran. Partisipasi anggaran memiliki tiga potensi masalah, yaitu menetapkan standar yang terlalu tinggi atau rendah, membuat kelonggaran dalam anggaran, dan partisipasi semu (Hansen dan Mowen, 2009). Dalam proses penyusunan anggaran, manajer cenderung membuat anggaran yang terlalu ketat atau terlalu longgar. Tujuan anggaran cenderung menjadi tujuan manajer ketika menyusun anggaran. Penetapan anggaran yang terlalu ketat merupakan tantangan bagi manajer yang agresif dan kreatif, sedangkan anggaran yang terlalu longgar merupakan kesempatan bagi manajer yang ingin mencapai anggarannya dengan mudah, sehingga mengurangi risiko yang harus dihadapi. Partisipasi dalam proses 
penyusunan anggaran juga memberikan kewenangan kepada para manajer untuk menetapkan isi anggaran. Kewenangan ini memberikan peluang bagi manajer untuk menyalahgunakan kewenangan yang dimiliki dengan mempermudah pencapaian anggaran sehingga dapat merugikan organisasi (Aprila dan Selvi, 2012).

Budgetary slack (senjangan anggaran) adalah proses penganggaran yang ditemukan adanya distorsi secara sengaja dengan menurunkan pendapatan yang dianggarkan dan meningkatkan biaya yang dianggarkan, dengan kata lain budgetary slack adalah perbedaan antara anggaran yang dinyatakan dengan estimasi anggaran terbaik yang secara jujur dapat diprediksinya. Penelitian mengenai budgetary slack telah banyak dilakukan sebelumnya, namun masih banyak ditemukan ketidakkonsistenan. Hasil penelitian Lowe dan Shaw (1968), Young (1985) dan Lukka (1988) menunjukkan bahwa partisipasi penganggaran memiliki pengaruh positif dan dapat meningkatkan terjadinya budgetary slack, karena individu-individu berpartisipasi dalam penyusunan anggaran dan mempunyai pengaruh terhadap target anggaran dengan tujuan mencari kemudahan dalam pencapaian anggaran yang ditetapkan dan menginginkan penghargaan atas pencapaian target anggaran tersebut. Namun, beberapa penelitian lain menunjukkan hasil yang berbeda, dimana penelitian yang dilakukan oleh Onsi (1973), Camman (1976), Merchant (1985) dan Dunk (1993) mengungkapkan bahwa partisipasi dalam penyusunan anggaran dapat mengurangi budgetary slack, karena agen membantu memberikan informasi kepada prinsipal tentang prospek masa depan sehingga anggaran yang disusun menjadi lebih akurat. Adanya 
partisipasi dalam penganggaran ini diharapkan mampu membantu jalannya penganggaran agar mencapai hasil yang baik. Govindarajan (1986) menyatakan bahwa perbedaan hasil dari penelitian sebelumnya bisa dipecahkan dengan menggunakan pendekatan kontinjensi. Hal tersebut dilakukan dengan cara memasukan variabel lain yang mungkin mempengaruhi hubungan partisipasi penganggaran pada budgetary slack. Variabel yang diperkirakan dapat mempengaruhi hubungan partisipasi penganggaran dengan budgetary slack tersebut adalah self esteem dan group cohesiveness. Banyak teori yang mengatakan bahwa kohesivitas adalah teamwork. Karena tanda dari kelompok dengan kohesivitas tinggi adalah timbulnya rasa saling memiliki dan bertanggungjawab terhadap hasil usaha kelompoknya.

Sharma dan Agarwala (2013) meyebutkan bahwa self esteem adalah kepercayaan diri seseorang, kepuasan diri terhadap suatu hal dan rasa menghormati diri sendiri. Hal tersebut meliputi keyakinan tentang kemampuan diri sendiri dan kelayakan. Seseorang dengan self esteem yang rendah cenderung tidak dapat bekerja dengan baik. Dengan mental seperti itu individu akan cenderung melakukan budgetary slack karena tidak percaya dengan kemampuannya sendiri sehingga berasumsi apakah anggaran yang dibuat dapat tercapai (Bateman, 2006). Sehingga self esteem merupakan suatu keyakinan nilai diri sendiri berdasarkan evaluasi diri secara keseluruhan. Seseorang dengan self esteem yang tinggi dimana mereka melihat dirinya berharga, mampu dan dapat diterima. Orang dengan self esteem rendah merasa kurang baik dengan dirinya. Orang yang memiliki self esteem tinggi cenderung memandang diri mereka 
sendiri sebagai seorang yang penting, berharga, berpengaruh dan berarti dalam konteks organisasi yang mempekerjakan mereka (Hapsari,2011). Hasil penelitian Hapsari (2011), Ardianti (2015), dan Sari (2017) menyatakan, self esteem mampu memperlemah partispasi anggaran terhadap budgetary slack

Penelitian Permata (2015), Putri (2015) dan Arimbawa (2017) menyatakan bahwa group cohesiveness memperlemah pengaruh partisipasi anggaran terhadap budgetary slack. Penelitian mengenai group cohesiveness pun dilakukan oleh Djasuli dan Fadilah (2011), serta Dwisariasih (2013) yang menghasilkan kesimpulan bahwa group cohesiveness berpengaruh signifikan positif terhadap hubungan partisipasi anggaran dengan budgetary slack.

Fahrianta dan Ghozali (2002) mengatakan apabila penelitian-penelitian terdahulu memiliki perbedaan hasil, maka kemungkinan terdapat hal lain pada faktor partisipasi anggaran dan budgetary slack yang dapat terlibat dalam hubungan kedua unsur tersebut. Perbedaan temuan pada penelitian terdahulu dapat diselaraskan dengan menerapkan pendekatan kontinjensi (Govindarajan, 1986). Pendekatan kontinjensi merupakan sebuah rancangan yang mengatakan bahwa sebuah sistem kontrol tidak dapat diterapkan pada seluruh organisasi dan sebuah sistem yang benar harus mengamati adanya faktor lain di luar sistem yang kemungkinan dapat terlibat pada sebuah organisasi (Otley, 1980).

Budgetary slack sering dihubungkan dengan masalah pada organisasi atau faktor perilaku individu pada saat menyusun anggaran yang dapat menyebabkan terjadinya budgetary slack. Self esteem merupakan faktor yang dapat mempengaruhi perilaku seseorang, sehingga self esteem diduga merupakan faktor 
yang dapat mempengaruhi hubungan partisipasi anggaran pada budgetary slack, karena self esteem merupakan evaluasi diri seseorang dimana seorang individu yakin akan kapasitas yang dimiliki. Dalam hubungannya dengan budgetary slack, seseorang dengan self esteem yang tinggi akan merasa bahwa dirinya berpengaruh dalam tahap penyusunan anggaran, dan berusaha sebaik mungkin untuk menghindari kesalahan, sehingga dapat menurunkan tingkat budgetary slack.

Penelitian yang dilakukan Hapsari (2011), Ardianti (2015), dan Sari (2017) menyatakan, self esteem mampu memperlemah partispasi anggaran terhadap budgetary slack. Hasil tersebut memiliki arti apabila seseorang merasa dirinya begitu penting, berharga dan berpengaruh maka timbul kepercayaan diri bahwa apa yang dilakukannya akan berhasil dan menciptakan hasil yang optimal sehingga menurunkan kecenderungan individu yang berpartisipasi dalam penyusunan anggaran untuk menciptakan senjangan. Teori kontinjensi dan penelitian sebelumnya mendasari perumusan hipotesis berikut:

$\mathrm{H}_{1}$ : Self Esteem memperlemah pengaruh partisipasi anggaran pada budgetary slack

Fahrianta dan Ghozali (2002) mengatakan apabila penelitian-penelitian terdahulu memiliki perbedaan hasil, maka kemungkinan terdapat hal lain pada faktor partisipasi anggaran dan budgetary slack yang dapat terlibat dalam hubungan kedua unsur tersebut. Perbedaan temuan pada penelitian terdahulu dapat diselaraskan dengan menerapkan pendekatan kontinjensi (Govindarajan, 1986). Berkaitan dengan budgetary slack, group cohesiveness merupakan faktor lain yang dapat mempengaruhi perilaku seseorang, sehingga group cohesiveness diduga merupakan faktor yang dapat mempengaruhi hubungan partisipasi 
anggaran pada budgetary slack, karena group cohesiveness merupakan kekuatan ketertarikan anggota yang tetap pada kelompoknya daripada terhadap kelompok lain.

Kelompok formal dan informal dapat memiliki kedekatan atau kesamaan dalam sikap, prilaku, dan prestasi (Falikhatun, 2007). Kedekatan ini disebut sebagai group cohesiveness yang umumnya dikaitkan dengan dorongan anggota untuk tetap bersama dalam kelompoknya dibanding dorongan untuk mendesak anggota keluar dari kelompok (Gibson, 2003). Konsep group cohesiveness penting untuk pemahaman sebuah kelompok dalam organisasi. Semakin para anggota kelompok saling tertarik dan makin sepakat terhadap sasaran kelompok, maka akan semakin lekat atau semakin kohesif kelompok tersebut. Tingkat kohesivitas bisa mempunyai akibat positif atau negatif tergantung seberapa baik tujuan kelompok tersebut dan sesuai dengan tujuan organisasi formal. Bila kohesivitas tinggi dan kelompok menerima serta sepakat dengan tujuan formal organisasi, maka perilaku kelompok akan positif ditinjau dari sisi organisasi formal. Tetapi bila ada kelompok yang sangat kohesif dan tujuannya tidak sejalan dengan organisasi formal, maka perilaku kelompok akan negatif ditinjau dari sisi organisasi formal (Robbins, 1996).

Penelitian yang dilakukan Permata (2015), Putri (2015) dan Arimbawa (2017) menyatakan, group cohesiveness memiliki kolerasi negatif terhadap hubungan partisipasi anggaran dengan budgetary slack. Hasil tersebut memiliki arti bahwa group cohesiveness yang tinggi akan memperjelas tujuan kelompok secara khusus yang nantinya akan memperjelas tujuan organisasi secara 
keseluruhan, sehingga dengan adanya group cohesiveness dapat membuat budgetary slack yang timbul awalnya tinggi menjadi rendah. Teori kontinjensi dan penelitian sebelumnya mendasari perumusan hipotesis berikut:

$\mathrm{H}_{2}$ : Group cohesiveness memperlemah pengaruh partisipasi anggaran pada budgetary slack

\section{METODE PENELITIAN}

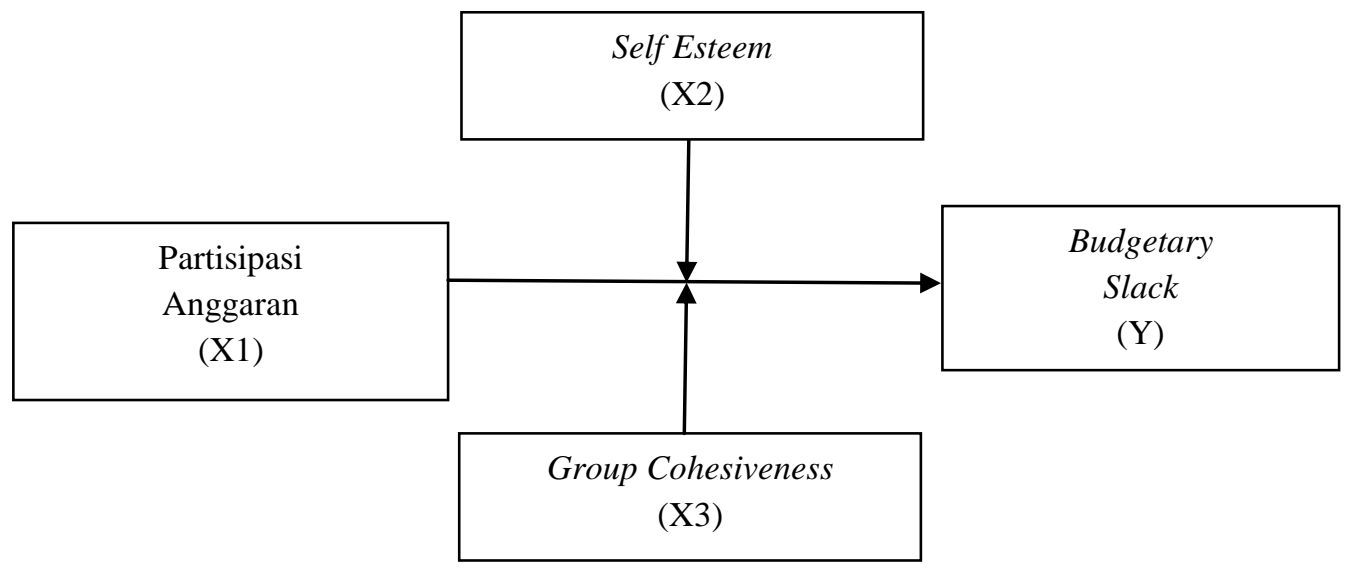

Sumber : Data diolah 2018

\section{Gambar 1. DesainPenelitian}

Penelitian ini menggunakan pendekatan kuantitatif dengan metode deskriptif. Pendekatan kuantitatif mengutamakan objektifitas desain penelitian dengan menggunakan angka-angka dan pengolahan statistik dan hasil yang diperoleh dapat digunakan untuk mengungkap kohesivitas kelompok. Adapun metode deskriptif merupakan metode penelitian yang bertujuan mendeskripsikan suatu keadaan atau fenomena apa adanya.

Lokasi penelitian dilakukan di Bank Perkreditan Rakyat (BPR) yang berada di Kota Denpasar. Sedangkan subjek dalam penelitian adalah para penyusun anggaran di BPR (Bank Perkreditan Rakyat) yang tersebar di Kota Denpasar 
sebanyak 22 perusahaan. Objek dari penelitian ini adalah self esteem dan group cohesiveness sebagai variabel pemoderasi pengaruh partisipasi anggaran terhadap budgetary slack.

Variabel terikat dalam penelitian ini adalah budgetary slack(Y) yang diukur dengan menggunakan indikator perbedaan jumlah anggaran yang dinyatakan dengan estimasi terbaik, kelonggaran dalam anggaran, standar anggaran dan keinginan untuk mencapai target. Variabel bebas dalam penelitian ini adalah partisipasi anggaran (X1) yang diukur dengan menggunakan tiga indikator yaitu Keikutsertaan dalam penyusunan anggaran, Besarnya pengaruh terhadap penetapan anggaran, dan Kebutuhan memberikan pendapat.

Variabel moderasi dalam penelitian ini adalah Self Esteem (X2) dan Group Cohesiveness (X3) yang masing-masing diukur dengan menggunakan indikator. Self Esteem diukur dengan menggunakan lima indikator yaitu Merasa sangat berharga, Merasa memiliki kualitas yang tinggi, Merasa mampu melakukan sesuatu, Merasa mengambil tindakan positif, dan Merasa puas. Group Cohesiveness diukur dengan menggunakan empat indikator yaitu kekuatan sosial, kesatuan dalam kelompok, daya tarik dan kerjasama kelompok.

Jenis data yang digunakan dalam penelitian ini adalah data kualitatif berupa nama-nama BPR yang terdaftar di Kota Denpasar dan kuesinoner yang digunakan oleh peneliti. Data kuantitatif dalam penelitian berupa skor jawaban kuesioner yang diperoleh dengan skala likert 4 point. Sedangkan sumber data yang digunakan dalam penelitian ini adalah sumber primer berupa jawaban responden 
terhadap item-item pertanyaan yang terdapat dalam empat instrumen penelitian yaitu partisipasi anggaran, budgetary slack, self esteem dan group cohesiveness.

Populasi dalam penelitian ini adalah seluruh pejabat atau pegawai yang terlibat dalam proses penyusun anggaran pada 22 BPR di Kota Denpasar. Pemilihan sampel penelitian didasarkan pada teknik purposive sampling. Responden dalam penelitian ini adalah seorang direktur beserta 4 kepala bagian di masing-masing bagian pada 22 BPR di Kota Denpasar yang telah menduduki jabatan minimal satu tahun. Pemilihan responden pada setiap BPR dengan seorang direktur beserta 4 kepala bagian dikarenakan setiap BPR di Kota Denpasar memiliki struktur organisasi yang berbeda-beda sehingga menggunakan jumlah minimal kepala bagian. Jumlah kuesioner yang disebarkan di setiap BPR berjumlah 5 kuesioner.

Metode pengumpulan data yang digunakan adalah metode survei berupa kuesioner. Kuesioner yang disebarkan berupa daftar pernyataan tertulis kepada responden mengenai partisipasi anggaran, budgetary slack, self esteem, dan group cohesiveness. Masing-masing variabel tersebut disiapkan dengan jumlah pernyataan yang berbeda satu dengan yang lainnya. Kuesioner disertai surat pemohonan untuk menjadi responden diberikan secara langsung.

Teknik analisis data yang digunakan dalam penelitian ini adalah teknik analisis regresi moderasi. Sebelum melakukan pengujian regresi moderasi, terdapat beberapa asumsi yang harus dipenuhi agar data yang akan dimasukkan dalam model regresi telah memenuhi ketentuan dan syarat dalam regresi. Uji 
asumsi klasik dalam penelitian ini mencakup uji normalitas, heteroskedastisitas, dan multikolinearitas. Model regresi linier berganda dirumuskan sebagai berikut.

$Y=\alpha+\beta_{1} X_{1}+\beta_{2} X_{2}+\beta_{3} X_{3}+\beta_{4} X_{1} X_{2}+\beta_{5} X_{1} X_{3}+e$

Keterangan:

$\begin{array}{ll}\mathrm{Y} & =\text { Budgetary Slack } \\ \alpha & =\text { Konstanta } \\ \mathrm{X}_{1} & =\text { Variabel Partisipasi anggaran } \\ \mathrm{X}_{2} & =\text { Variabel Self Esteem } \\ \mathrm{X}_{3} & =\text { Variabel Group Cohesiveness } \\ \mathrm{e} & =\text { Standar Error } \\ \beta_{1 .} \beta_{2 .} \beta_{3 .} \beta_{4 .} \beta_{5 .} & =\text { Koefisien Regresi }\end{array}$

\section{HASIL DAN PEMBAHASAN}

Karakteristik demografi dan profil 84 yang terdiri dari direktur dan kepala bagian disajikan seperti pada Tabel 1. Karakteristik responden tersebut meliputi jenis kelamin, umur jabatan, pendidikan terakhir, dan lamanya.

Berdasarkan Tabel 1. dapat diketahui bahwa responden yang berjenis kelamin pria berjumlah 51 orang $(60,7 \%)$ dan berjenis kelamin wanita berjumlah 39 orang $(39,3 \%)$. Responden dalam penelitian ini berusia rata-rata 35-50 tahun dengan jumlah 59 orang $(70,2 \%)$. Kriteria pendidikan terakhir digunakan untuk mengetahui tingkat pendidikan dari responden pada penelitian ini. Pada tabel diatas dapat dilihat jumlah responden dengan tingkat pendidikan SMA sebanyak 12 orang (14,3\%), tingkat pendidikan Diploma sebanyak 7 orang $(8,3 \%)$, sedangkan tingkat pendidikan S1 sebanyak 60 orang $(71,4 \%)$ dan dengan tingkat pendidikan S2 sebanyak 5 orang $(6,0 \%)$. Responden dalam penelitian ini menduduki posisi sebagai Direktur yaitu sebanyak 16 orang $(19,2 \%)$, menduduki 
jabatan Kepala Bagian Personaliadan Umum yaitu sebanyak 18 orang (21,4\%), menduduki jabatan Kepala Bagian Kredit yaitu sebanyak 15 orang (17,9\%), menduduki jabatan Kepala Bagian Dana yaitu sebanyak 18 orang $(21,4 \%)$, dan menduduki jabatan Kepala Bagian Accounting sebanyak 17 orang (20,2\%). Selain itu, dapat di lihat dari tabel di atas bahwa responden paling lama bekerja selama $>20$ tahun, dengan jumlah 33 orang atau 39,3\%.

Tabel 1.

Demografi Responden

\begin{tabular}{|c|c|c|c|}
\hline No & Kriteria & Jumlah & Persentase \\
\hline 1 & $\begin{array}{l}\text { Jenis Kelamin } \\
\text { - Pria } \\
\text { - Wanita }\end{array}$ & $\begin{array}{l}51 \text { orang } \\
33 \text { orang }\end{array}$ & $\begin{array}{l}60,7 \% \\
39,3 \%\end{array}$ \\
\hline 2 & $\begin{array}{l}\text { Umur } \\
-<35 \text { tahun } \\
-35-50 \text { tahun } \\
->50 \text { tahun }\end{array}$ & $\begin{array}{l}13 \text { orang } \\
59 \text { orang } \\
12 \text { orang }\end{array}$ & $\begin{array}{l}15,5 \% \\
70,2 \% \\
14,3 \%\end{array}$ \\
\hline 3 & $\begin{array}{l}\text { Pendidikan Terakhir } \\
\text { - SMA } \\
-\quad \text { Diploma } \\
-\quad \text { S1 } \\
-\quad \text { S2 }\end{array}$ & $\begin{array}{r}12 \text { orang } \\
7 \text { orang } \\
60 \text { orang } \\
5 \text { orang }\end{array}$ & $\begin{array}{r}14,3 \% \\
8,3 \% \\
71,4 \% \\
6,0 \%\end{array}$ \\
\hline 4 & $\begin{array}{l}\text { Jabatan/Bagian } \\
\text { - Direktur } \\
\text { - Kepala Bagian Personalia dan Umum } \\
\text { - Kepala Bagian Kredit } \\
\text { - Kepala Bagian Dana } \\
\text { - Kepala Bagian Accounting }\end{array}$ & $\begin{array}{l}16 \text { orang } \\
18 \text { orang } \\
15 \text { orang } \\
18 \text { orang } \\
17 \text { orang }\end{array}$ & $\begin{array}{l}19,1 \% \\
21,4 \% \\
17,9 \% \\
21,4 \% \\
20,2 \%\end{array}$ \\
\hline 5 & $\begin{array}{l}\text { Lama Bekerja } \\
-<5 \text { tahun } \\
-5-10 \text { tahun } \\
-10-20 \text { tahun } \\
->20 \text { tahun }\end{array}$ & $\begin{array}{r}8 \text { orang } \\
19 \text { orang } \\
24 \text { orang } \\
33 \text { orang }\end{array}$ & $\begin{array}{r}9,5 \% \\
22,6 \% \\
28,6 \% \\
39,3 \%\end{array}$ \\
\hline
\end{tabular}

Sumber: Data diolah, 2018

Suatu instrumen yang valid ditunjukkan dengan $\mathrm{r}$ Pearson Correlation $\geq$ 0,30. Berikut hasil uji validitas pada Tabel 2 . 
Tabel 2.

Hasil Uji Validitas

\begin{tabular}{|c|c|c|c|c|}
\hline No & Variabel & Item Pernyataan & Korelasi Item Total & Keterangan \\
\hline \multirow{7}{*}{1} & \multirow{6}{*}{$\begin{array}{c}\text { Partisipasi Anggaran } \\
\left(\mathrm{X}_{1}\right)\end{array}$} & X1.1 & & Valid \\
\hline & & $\mathrm{X} 1.2$ & & Valid \\
\hline & & $\mathrm{X} 1.3$ & & Valid \\
\hline & & $\mathrm{X} 1.4$ & & Valid \\
\hline & & $\mathrm{X} 1.5$ & & Valid \\
\hline & & $\mathrm{X} 1.6$ & & Valid \\
\hline & \multirow{5}{*}{ Self Esteem $\left(\mathrm{X}_{2}\right)$} & $\mathrm{X} 1.1$ & & Valid \\
\hline \multirow{4}{*}{2} & & $\mathrm{X} 1.2$ & & Valid \\
\hline & & $\mathrm{X} 1.3$ & & Valid \\
\hline & & $\mathrm{X} 1.4$ & & Valid \\
\hline & & $\mathrm{X} 1.5$ & & Valid \\
\hline \multirow{15}{*}{3} & \multirow{15}{*}{$\begin{array}{c}\text { Group Cohesivenes } \\
\left(\mathrm{X}_{3}\right)\end{array}$} & $\mathrm{X} 1.1$ & & Valid \\
\hline & & $\mathrm{X} 1.2$ & & Valid \\
\hline & & $\mathrm{X} 1.3$ & & Valid \\
\hline & & $\mathrm{X} 1.4$ & & Valid \\
\hline & & $\mathrm{X} 1.5$ & & Valid \\
\hline & & $\mathrm{X} 1.6$ & & Valid \\
\hline & & $\mathrm{X} 1.7$ & & Valid \\
\hline & & $\mathrm{X} 1.8$ & & Valid \\
\hline & & X1.9 & & Valid \\
\hline & & $\mathrm{X} 1.10$ & & Valid \\
\hline & & $\mathrm{X} 1.11$ & & Valid \\
\hline & & $\mathrm{X} 1.12$ & & Valid \\
\hline & & $\mathrm{X} 1.13$ & & Valid \\
\hline & & $\mathrm{X} 1.14$ & & Valid \\
\hline & & $\mathrm{X} 1.15$ & & Valid \\
\hline \multirow{8}{*}{4} & \multirow{8}{*}{ Budgetary Slack $(\mathrm{Y})$} & $\mathrm{X} 1.1$ & & Valid \\
\hline & & $\mathrm{X} 1.2$ & & Valid \\
\hline & & $\mathrm{X} 1.3$ & & Valid \\
\hline & & $\mathrm{X} 1.4$ & & Valid \\
\hline & & $\mathrm{X} 1.5$ & & Valid \\
\hline & & X1.6 & & Valid \\
\hline & & $\mathrm{X} 1.7$ & & Valid \\
\hline & & $\mathrm{X} 1.8$ & & Valid \\
\hline
\end{tabular}

Sumber: Data diolah, 2018

Berdasarkan Tabel 2. dapat diketahui bahwa nilai koefisien korelasi untuk semua variabel dan setiap butir pernyataan memiliki nilai lebih dari 0,30. Sehingga instrumen penelitian yang terdiri dari butir-butir pernyataan partisipasi 
anggaran $\left(\mathrm{X}_{1}\right)$, self esteem $\left(\mathrm{X}_{2}\right)$, group cohesiveness $\left(\mathrm{X}_{3}\right)$, dan budgetary slack $(\mathrm{Y})$ memenuhi kriteria valid.

Uji reliabilitas mampu menunjukan sejauh mana instrument dapat dipercaya dan diharapkan. Nilai suatu instrument dikatakan reliable apabila nilai Alpha Cronbach $\geq 0,60$. Hasil uji reliabilitas dapat dilihat pada Tabel 3 .

Tabel 3.

Hasil Uji Reliabilitas

\begin{tabular}{lcc}
\hline \multicolumn{1}{c}{ Variabel } & Koefisien Cronbach's Alpha & Keputusan \\
\hline Partisipasi Anggaran $\left(\mathrm{X}_{1}\right)$ & 0,922 & Reliabel \\
Self esteem $\left(\mathrm{X}_{2}\right)$ & 0,906 & Reliabel \\
Group cohesiveness $\left(\mathrm{X}_{3}\right)$ & 0,972 & Reliabel \\
Budgetary slack $(\mathrm{Y})$ & 0,948 & Reliabel \\
\hline Sumber: Data diolah, 2018 & &
\end{tabular}

Berdasarkan informasi pada Tabel 3. diatas, data yang diperoleh dari penelitian menunjukkan bahwasanya variabel Partisipasi Anggaran $\left(\mathrm{X}_{1}\right)$, Self esteem $\left(\mathrm{X}_{2}\right)$, Group cohesiveness $\left(\mathrm{X}_{3}\right)$, dan Budgetary slack $(\mathrm{Y})$ memiliki nilai koefisien cronbach alpha diatas 0,60. Nilai cronbach alpha diatas 0,60 menunjukkan bahwa seluruh instrumen memenuhi kriteria reliabel.

Uji normalitas menggunakan uji Kolmogorov-Smirnov, dengan uji ini dapat diketahui data yang digunakan berdistribusi normal atau tidak. Apabila Sign $t$ hitung $>0.05$, maka data tersebut berdistribusi normal dan begitu juga sebaliknya (Santoso, 2001).

Tabel 4.

Hasil Uji Normalitas

\begin{tabular}{lc}
\hline & Unstandardized Residual \\
\hline $\mathrm{N}$ & 84 \\
Test Statistic & 0,093 \\
Asymp. Sig. (2-tailed) & 0,069 \\
\hline
\end{tabular}

Sumber : Data diolah, 2018

Berdasarkan hasil pengujian SPSS pada Tabel 4., hasil uji normalitas dengan $\mathrm{N}=84$ besarnya nilai Kolmogorov- Smirnof dari keempat variabel yaitu 
partisipasi anggaran, self esteem, group cohesiveness dan budgetary slack adalah 0,093 dan nilai koefisien Asymp. Sig. (2-tailed)sebesar 0,069. Dengan hasil uji ini menunjukkan bahwa data telah berdistribusi normal.

Uji Heteroskedastisitas bertujuan untuk menguji apakah dalam model terjadi ketidaksamaan varian atau residual satu pengamatan ke pengamatan lainnya. Jika tingkat signifikan lebih besar dari 0,05 maka terjadi heteroskedastisitas.

Tabel 5.

Hasil Uji Heteroskedastisitas

\begin{tabular}{lcl}
\hline \multicolumn{1}{c}{ Variabel } & Sig. & Keterangan \\
\hline Partisipasi Anggaran $\left(\mathrm{X}_{1}\right)$ & 0,087 & Tidak ada heterokedastisitas \\
Self esteem $\left(\mathrm{X}_{2}\right)$ & 0,258 & Tidak ada heterokedastisitas \\
Group cohesiveness $\left(\mathrm{X}_{3}\right)$ & 0,275 & Tidak ada heterokedastisitas \\
Moderasi $\left(\mathrm{X}_{1 \_} \mathrm{X}_{2}\right)$ & 0,722 & Tidak ada heterokedastisitas \\
Moderasi $\left(\mathrm{X}_{1 \_} \mathrm{X}_{3}\right)$ & 0,237 & Tidak ada heterokedastisitas \\
\hline Sumber: Data diolah, 2018 & &
\end{tabular}

Berdasarkan hasil SPSS pada Tabel 5. dapat diketahui bahwa nilai signifikansi masing-masing variabel besarnya melebihi 0,05 . Hal ini menunjukkan bahwa model yang dibuat tidak mengandung gejala heteroskedastisitas, sehingga layak digunakan untuk memprediksi.

Uji multikolinieritas digunakan untuk mengetahui apakah antara variabel bebas terjadi multikolinieritas atau tidak. Uji yang digunakan yaitu dengan melihat nilai VIF (Varian Inflation Factor) dan Tolerance pada proses regresi biasa, jika keduanya mendekati 1 atau besaran VIF kurang dari 10 maka model tidak terkena multikolinieritas. Berdasasrkan hasil pengujian multikolinearitas dapat diperoleh hasil sebagai berikut. 
Tabel 6.

Hasil Uji Multikolinieritas

\begin{tabular}{lccl}
\hline \multicolumn{1}{c}{ Variabel } & Toleransi & VIF & Keterangan \\
\hline Partisipasi Anggaran $\left(\mathrm{X}_{1}\right)$ & 0,591 & 1,693 & Tidak ada multikolinearitas \\
Self esteem $\left(\mathrm{X}_{2}\right)$ & 0,761 & 1,315 & Tidak ada multikolinearitas \\
Group cohesiveness $\left(\mathrm{X}_{3}\right)$ & 0,562 & 1,778 & Tidak ada multikolinearitas \\
Moderasi $\left(\mathrm{X}_{1} \mathrm{X}_{2}\right)$ & 0,891 & 1,122 & Tidak ada multikolinearitas \\
Moderasi $\left(\mathrm{X}_{1 \_} \mathrm{X}_{3}\right)$ & 0,459 & 2,179 & Tidak ada multikolinearitas \\
\hline
\end{tabular}

Sumber : Data diolah, 2018

Berdasarkan hasil SPSS pada Tabel 6. dapat diketahui bahwa nilai toleransi pada masing-masing variabel diatas 0,1 dan nilai VIF dibawah 10 . Hasil tersebut berarti bahwa tidak terdapat gejala mutlikolinearitas dari model regresi yang dibuat, sehingga model tersebut layak digunakan untuk memprediksi

Sesuai dengan hasil perhitungan dengan menggunakan program SPSS for windows maka diperoleh hasil analisis regresi linear berganda seperti berikut.

Tabel 7.

Hasil Uji Regresi Moderasi

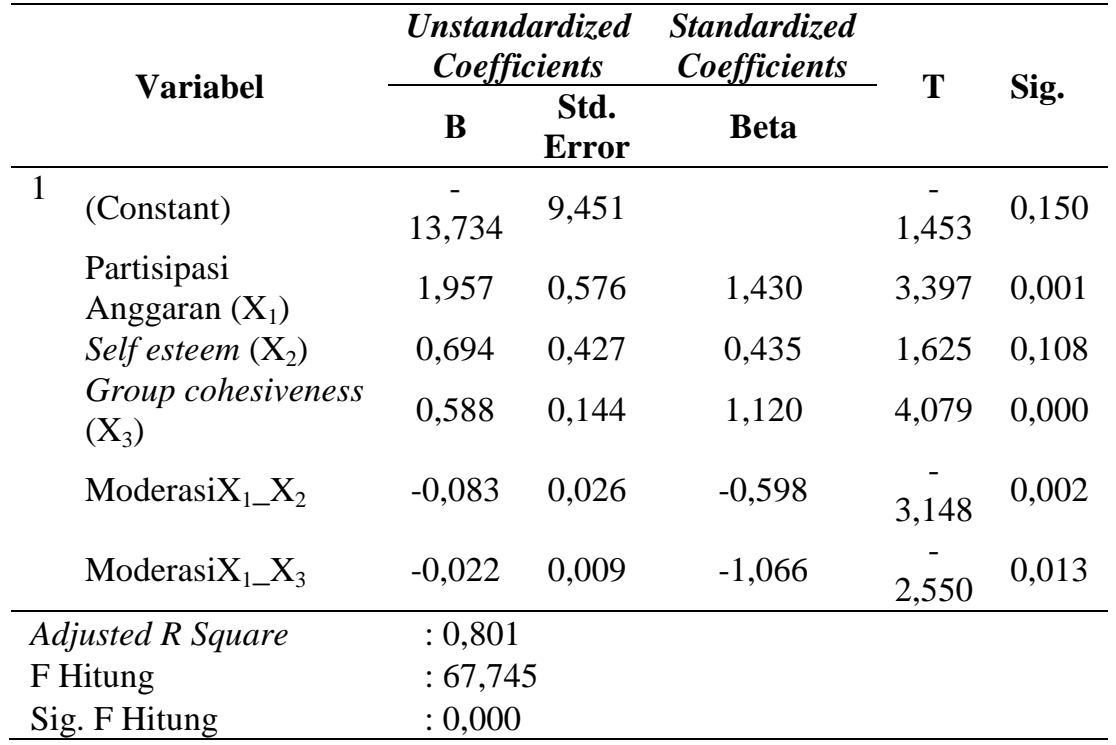

Sumber: Data diolah, 2018 
Berdasarkan Tabel 7. dapat dibuat suatu model persamaan regresi moderasi yaitu sebagai berikut:

$Y=-13,734+1,957 X_{1}-0,694 X_{2}+0,588 X_{3}-0,083 X_{1} X_{2}-0,022 X_{1} X_{3+} e$

Nilai koefisien regresi $\beta_{4}$ sebesar $-0,083$ bertanda negatif mengindikasikan bahwa apabila interaksi variabel partisipasi anggaran $\left(\mathrm{X}_{1}\right)$ dan self esteem $\left(\mathrm{X}_{2}\right)$ meningkat sebesar 1, maka variabel budgetary slack (Y) akan mengalami penurunan sebesar 0,083 . Nilai koefisien regresi $\beta_{5}$ sebesar $-0,022$ bertanda negatif mengindikasikan bahwa apabila interaksi partisipasi anggaran $\left(\mathrm{X}_{1}\right)$ dan group cohesiveness $\left(\mathrm{X}_{3}\right)$ meningkat sebesar 1 , maka variabel budgetary slack $(\mathrm{Y})$ akan mengalami penurunan sebesar 0,022 .

Berdasarkan Tabel 7. menunjukkan bahwa koefisien determinasi yaitu nilai adjusted $R^{2}$ adalah 0,801 atau 80,1 persen, ini artinya sebesar 80,1 persen variasi budgetary slack dipengaruhi oleh model yang dibentuk oleh Partisipasi Anggaran $\left(\mathrm{X}_{1}\right)$, Self esteem $\left(\mathrm{X}_{2}\right)$, dan group cohesiveness $\left(\mathrm{X}_{3}\right)$ sedangkan sisanya 19,9 persen dijelaskan oleh variabel lain di luar model yang tidak diteliti dalam penelitian ini.

Uji kelayakan model bertujuan untuk mengetahui apakah model regresi yang digunakan dalam penelitian ini layak atau tidak digunakan sebagai alat analisis untuk menguji pengaruh variabel bebas pada variabel terikatnya.

Tabel 8.

Hasil Uji F (Kelayakan Model)

\begin{tabular}{llccccc}
\hline & Model & Sum Of Squares & Df & Mean Square & F & Sig. \\
\hline 1 & Regression & 601,545 & 5 & 120,309 & 45,007 & 0,000 \\
& Residual & 69,500 & 26 & 2,673 & & \\
& Total & 671,045 & 31 & & & \\
\hline
\end{tabular}

Sumber: Data diolah, 2018 
Berdasarkan Tabel 8. dapat diketahui bahwa nilai signifikansi $F=0,000$ yang lebih kecil dari nilai $\alpha=0,05$, hal ini menunjukkan bahwa variabel independen mampu memprediksi atau menjelaskan fenomena budgetary slack pada BPR di Kota Denpasar dan menunjukkan bahwa model yang digunakan pada penelitian ini adalah layak untuk diteliti.

Uji hipotesis bertujuan untuk mengetahui apakah masing-masing variabel independen mempunyai pengaruh secara signifikan pada variabel dependennya. Level of significant yang digunakan adalah 0,05 (5\%). Apabila probabilitas signifikansi lebih kecil dari 0,05 maka H0 ditolak dan H1 diterima. Berdasarkan Tabel 7. maka hasil pengujian secara parsial masing-masing variabel independen terhadap dependen dapat dijabarkan sebagi berikut.

Berdasarkan pada Tabel 7. diketahui bahwa tingkat signifikansi untuk variabel moderat self esteem mempengaruhi hubungan antara partisipasi anggaran pada budgetary slack sebesar 0,002, nilai ini lebih kecil dari $\alpha=0,05(0,002<$ 0,05). Ini berarti self esteem mampu memoderasi pengaruh partisipasi anggaran terhadap budgetary slack. Selanjutnya untuk melihat apakah arahnya positif atau negatif dilihat dari koefisien $\beta$, pada Tabel 7. koefisien $\beta$ negatif sebesar 0,083 . Hal ini menunjukkan bahwa self esteem $\left(\mathrm{X}_{2}\right)$ mampu memperlemah pengaruh partisipasi anggaran pada budgetary slack $(\mathrm{Y})$, sehingga hipotesis pertama $\left(\mathrm{H}_{1}\right)$ diterima.

Hipotesis pertama $\left(\mathrm{H}_{1}\right)$ yang dikemukakan dalam penelitian ini adalah self esteem mampu memperlemah pengaruh partisipasi anggaran pada budgetary slack. Hasil pengujian hipotesis menunjukkan bahwa variabel self esteem 
memperlemah pengaruh partisipasi anggaran pada budgetary slack. Jika self esteem yang dimiliki oleh individu yang berpartisipasi dalam penganggaran tinggi, maka kemungkinan terjadinya budgetary slack di BPR se-kota Denpasar akan menurun.

Hasil penelitian ini konsisten dengan hasil penelitian Hapsari (2011), Ardianti (2015), dan Sari (2017) yang menemukan bahwa self esteem mampu memperlemah pengaruh partisipasi anggaran pada budgetary slack. Para peneliti mendefnisikan self esteem dalam organisasi sebagai nilai yang dimiliki oleh individu atas dirinya sendiri sebagai anggota organisasi yang bertindak dalam konteks organisasi. Hasil penelitian ini membuktikan kebenaran teori kontijensi, dimana terdapat faktor tertentu yaitu self esteem yang dapat mempengaruhi hubungan partisipasi anggaran terhadap budgetary slack.

Orang yang memiliki self esteem tinggi cenderung memandang diri mereka sendiri sebagai sebagai orang yang penting, berharga, berpengaruh dan berarti dalam konteks organisasi yang mempekerjakan mereka (Kreitner\&Kinicki, 2003). Dengan demikian self esteem mampu memperlemah pengaruh partisipasi anggaran pada budgetary slack, karena jika seseorang merasa dirinya begitu berharga, berpengaruh dan penting maka timbul kepercayaan diri bahwa apa yang dilakukannya akan berhasil dan menciptakan hasil yang optimal sesuai dengan tujuan organisasinya.

Berdasarkan Tabel 7. diketahui bahwa tingkat signifikansi untuk variabel moderat group cohesiveness mempengaruhi hubungan antara partisipasi anggaran pada budgetary slack sebesar 0,013, nilai ini lebih kecil dari $\alpha=0,05(0,013<$ 
0,05). Ini berarti group cohesiveness mampu memoderasi pengaruh partisipasi anggaran terhadap budgetary slack. Selanjutnya untuk melihat apakah arahnya positif atau negatif dilihat dari koefisien $\beta$, pada Tabel 7. koefisien $\beta$ negatif sebesar -0,022. Hal ini menunjukkan bahwa group cohesiveness $\left(\mathrm{X}_{3}\right)$ mampu memperlemah pengaruh partisipasi anggaran pada budgetary slack $(\mathrm{Y})$, sehingga hipotesis kedua $\left(\mathrm{H}_{2}\right)$ diterima.

Hipotesis kedua $\left(\mathrm{H}_{2}\right)$ yang dikemukakan dalam penelitian ini adalah group cohesiveness mampu memperlemah pengaruh partisipasi anggaran pada budgetary slack. Hasil pengujian hipotesis menunjukkan bahwa variabel group cohesiveness memperlemah pengaruh partisipasi anggaran pada budgetary slack. Jika group cohesiveness yang dimiliki oleh individu yang berpartisipasi dalam penganggaran tinggi, maka kemungkinan terjadinya budgetary slack di BPR se-kota Denpasar akan menurun.

Hasil penelitian ini konsisten dengan hasil penelitian Permata (2015), Putri (2015) dan Arimbawa (2017) yang menemukan bahwa group cohesiveness mampu memperlemah pengaruh partisipasi anggaran pada budgetary slack. Sehingga dalam partisipasi anggaran dibutuhkan group cohesiveness yang tinggi agar para individu tidak melakukan budgetary slack. Hasil penelitian ini membuktikan kebenaran teori kontijensi, dimana terdapat faktor tertentu yaitu group cohesiveness yang dapat mempengaruhi hubungan partisipasi anggaran terhadap budgetary slack.

Semakin para anggota kelompok saling tertarik dan makin sepakat terhadap sasaran kelompok, maka akan semakin lekat atau semakin kohesif kelompok 
tersebut.. Hal ini menunjukkan bahwa dengan adanya group cohesiveness yang tinggi akan memperjelas tujuan kelompok secara khusus yang nantinya akan memperjelas tujuan organisasi secara keseluruhan, sehingga para anggota kelompok secara bersama-sama akan berusaha mencapai tujuan organisasinya dan dapat membuat budgetary slack yang timbul awalnya tinggi menjadi semakin rendah.

\section{SIMPULAN}

Berdasarkan pembahasan hasil penelitian di atas, dapat disimpulkan bahwa self esteem mampu memperlemah pengaruh partisipasi anggaran pada budgetary slack dan group cohesiveness mampu memperlemah pengaruh partisipasi anggaran pada budgetary slack. Sedangkan saran yang dapat diberikan adalah BPR se-kota Denpasar harus lebih selektif dalam memilih pejabat maupun pegawai yang nantinya akan berpartisipasi dalam penyusunan anggaran yaitu yang memiliki self esteem yang tinggi. Selain itu harus bisa meningkatkan dan mengawasi group cohesiveness manajemennya agar tetap sejalan dengan tujuan organisasi. Penelitian selanjutnya dapat menemukan variabel-variabel baru yang dapat berpengaruh pada budgetary slack.

\section{REFERENSI}

Aprilia, N. dan S. Hidayani. (2012). The Effect Of Budgetary Participation, Asymmetry Information, Budget Emphasis and Comitment Organization To Budgetary Slack at Skpd Governmental Of Bengkulu City. Proceeding The 13th Malaysia Indonesia Conference on Economics, Management and Accounting (MIICEMA). 
Apriyandi. (2011). Pengaruh Informasi Asimetri Terhadap Hubungan Antara Anggaran Partisipasif dengan Budgetary Slack. Skripsi. Universitas Hasanudin.

Ardianti, P. N. H. (2015). Pengaruh Penganggaran Partisipatif pada Budgetary Slack dengan Asimetri Informasi, Self Esteem, Locus Of Control dan Kapasitas Individu Sebagai Variabel Moderasi (Studi pada Skpd Kabupaten Jembrana, Bali). Tesis. Universitas Udayana.

Arimbawa, I. W. A. (2017). Peran Kohesivitas Kelompok dalam Memoderasi Pengaruh Partisipasi Anggaran Terhadap Senjangan Anggaran pada Hotel Berbintang di Kota Denpasar. Skripsi. Universitas Udayana.

Armaeni. (2012). Analisis Pengaruh Partisipasi Anggaran, Informasi Asimetri dan nekanan Anggaran terhadap Senjangan Anggaran (Budgetary Slack) (Studi pada SKPD Pemerintah Kabupaten Pinrang). Skripsi. Universitas Hasanuddin.

Arthaswadaya, A. (2015). Pengaruh Asimetri Informasi terhadap Budgetary Slack dengan Self Esteem sebagai Variabel Pemoderasi : Studi Eksperimen dalam Konteks Penganggaran Partisipatif. Skripsi. Universitas Negeri Yogyakarta.

Bachman, J. G., and P. M. O’Malley. (1977). Self-esteem in young men: A longitudinal analysis of the impact of educational and occupational attainment. Journal of Personality and Social Psychology, 35, 365-380.

Brownell, P. (1982). The Role of Accounting Data in Performance Evaluation, Budgetary Partisipative, and Organizational Effectiveness. Journal of Accounting Research, 20, 589-603.

Brownell, P. and J. Morris. (1983). Budgetary Participation, Motivation and Managerial Peformance. Working Paper.

Carreras, M., G. Susano., and David. (2009). The Relationship Between Trust and Budgetary Slack: an Empirical Study.

Camman, C. (1976). Effects of the Use of Control System. Accounting, Organizations, and Society, 4, 301-313.

Djasuli, M. and N. I. Fadilah. (2011). Efek Interaksi Informasi Asimetri, Budaya Organisasi, Group Cohesiveness dan Motivasi dalam Hubungan Kausal antara Budgeting Participation dan Budgetary slack. Proceeding PESAT (Psikologi, Ekonomi, Sastra, Arsitektur dan Sipil), 4(11), E1-E6. 
Dubois, B. and J. A. Burns. (1975). An Analysis of the Meaning of Question Mark Response Category in Attitude Scales. Educational and Psychological Measurement, 35(4), 869-884.

Dunk, A. S. (1993). The Efects of Budget Emphasis and Information Asymmetry on The Relation Between Budgetary Participation and Slack. The Accounting Review, 68(2), 400-410.

Dwisariasih, J. (2013). Pengaruh Asimetri Informasi, Budaya Organisasi dan Kohesivitas Kelompok Terhadap Hubungan Partisipasi Anggaran dengan Kesenjangan Anggaran (Studi Empiris pada Seluruh SKPD di Kota Padang). Skripsi. Universitas Negeri Padang.

Fahrianta, R. Y. dan I. Ghozali. (2002). Pengaruh Tidak Langsung Sistem Penganggaran Terhadap Kinerja Manajerial: Motivasi Sebagai Variabel Intervening. Jurnal Riset Akuntansi, Manajemen dan Ekonomi, 2(1), 77113.

Falikhatun. (2008). Interaksi Informasi Asimetri, Budaya Organisasi, dan Group Cohesiveness dalam Hubungan antara Partisipasi Penganggaran dan Budgetary Slack (Studi Kasus pada Rumah Sakit Umum Daerah se-Jawa Tengah). Media Riset Akuntansi, Auditing dan Informasi, 8(1), 65-84.

Febrian, Y. A. (2013). Pengaruh Partisipasi Anggaran, Penekanan Anggaran dan Kompensasi terhadap Senjangan Anggaran PT. Apacinti Corpora. Skripsi. Universitas Satya Wacana.

Forsyth, D. R. (1999). Group Dynamics. California: Brook/Cole Publishing Company.

Gibson, J., M. Ivancenvich., and J. H. Donely. (2003). Organization: Structure, processes, behaviour. Dalas: Business Publication.Inc.

Govindarajan, V. (1986). Impact of Participation in The Budgetary Process on Managerial Attitudes an Performance. Universalistic and Contingency Perspetive. Decisions Sciences, 17, 496-516.

Glossary, M. (2014). Definitions of Terms Used in This Budget.

Ghozali, I. (2013). Aplikasi Analisis Multivariat dengan Program IBM SPSS 21. Edisi 7. Semarang: Badan Penerbit Universitas Diponegoro.Sukarno, Edi. 2000. Sistem Pengendalian Manajemen: Suatu Pendekatan Praktis. Jakarta: PT Gramedia Pustaka Utama.

Hapsari, Y. (2011). Pengaruh Kapasitas Individu Terhadap Budgetary Slack dengan Self Esteem Sebagai Variable Poderasi. Tesis. Yogyakarta. 
Haryanti, I. (2012). Budgetary Participation: How it Affects Performance and Commitment. Accountancy Business and the Public Interest.

Jensen, M. C., and W. H. Meckling. (1979). Theory of the firm: Managerial behavior, agency cost and ownership structure. Journal of Financial Economics 3 Springer Netherlands, 305-360.

Kreitner, R. dan A. Kinicki. (2003). Perilaku Organisasi. Terjemahan: Erly Suandy. Edisi Pertama. Penerbit Salemba Empat. Jakarta.

Latuheru, B. P. (2005). Pengaruh Partisipasi Anggaran terhadap Senjangan Anggaran dengan Komitmen Organisasi sebagai Variabel Moderating. Jurnal Akuntansi \& Keuangan, 7, 117-130.

Lowe, E. A. dan R. W. Shaw. (1968). An Analysis of Managerial Biasing: Evidence From a Company's Budgeting Proses. The Journal of Management Studies, 304-315.

Lukka, K. (1988). Budgetary Biasing in Organizations: Theoritical Framework and Empirical Evidence. Accounting, Organization, and Society, 13, 281301.

Merchant, K. A. (1985). Budgeting and Propersity to Create Budgetary Slack. Accounting, Organization, and Society, 10, 201-210.

Onsi, M. (1973). Factor Analysis of Behavioral Variables Affecting Budgetary Slack. The Accounting Review, 48, 535-538.

Otley, D. T. (1980). The Contingency Theory of Management Accounting: Achievement and Prognosis. Readings in Accounting for Management Control, 83-106.

Permata, C. M. dan I. Wirasedana. (2015). Pengaruh Partisipasi Anggaran pada Senjangan Anggaran dengan Group Cohesiveness sebagai Variabel Moderasi. E-Jurnal Akuntansi, 10(2), 379-384.

Putranto, Y. A. (2012). Pengaruh Informasi Asimetri dan Group Cohesiveness terhadap Hubungan Partisipasi Penganggaran dengan Budgetary Slack. Jurnal Economia, 8(2).

Putra, Y. A. (2015). Karakter Personal sebagai Pemoderasi Pengaruh Partisipasi Penganggaran terhadap Senjangan Anggaran pada Bank Perkreditan Rakyat Di Kabupaten Badung. Skripsi. Universitas Udayana. 
Putri, A. C. (2015). Kohesivitas Kelompok sebagai Pemoderasi Pengaruh Partisipasi Penganggaran terhadap Senjangan Anggaran pada BPR di Kabupaten Badung. Skripsi. Universitas Udayana.

Robbins, S. P. (1996). Perilaku Organisasi. Terjemahan. Jakarta: PT Prenhallindo.

Sari, N. P. E. Y. (2017). Pengaruh Partisipasi Penganggaran pada Senjangan Anggaran dengan Kapasitas Individu, Self Esteem, Komitmen Organisasi, dan Penekanan Anggaran sebagai Variabel Pemoderasipada Satuan Kerja Perangkat Daerah (SKPD) di Kabupaten Gianyar. Skripsi. Universitas Udayana.

Siegel, G. and H. R. Marconi. (1989). Behavioral Accounting. South Western Publishing Co.

Stevens, D. E. (2002). The Effects of Reputation and Ethics on Budgetary Slack. Journal of Management Accounting Research, 14.

Sulistyaningsih, F. C. (1995). Pengaruh Self Esteem Terhadap Kemampuan Berpikir Kreatif Dan Sikap Kreatif Remaja. Skripsi. Universitas Gajah Mada Yogyakarta.

Widhiarso, W. (2010). Pengembangan Skala Psikologi : Lima Kategori Respons ataukah Empat Kategori Respons?. Yogyakarta: Universitas Gadjah Mada.

Winarni, T. T. (2014). Analisis Pengaruh Partisipasi Anggaran, Budget emphasis, dan Informasi Asimetris terhadap Slack Anggaran (Studi pada Satuan Kerja Pemerintah Daerah Kabupaten Wonogiri). Naskah Publikasi. Universitas Muhammadiyah Surakarta.

Young, S. M. (1985). Participative Budgeting: The Effects of Risk Aversion and Symmetric Information on Budgeting Slack. Journal of Accounting Research, 23(2), 829-842. 